\title{
Psychological Experience of Children and Adolescents with Homozygous Sickle Cell Disease in Brazzaville
}

\author{
Engoba Moyen"1,2, Ghislain Armel Mpandzou,3, Matimé Julianna Déborah Boukoulou1, \\ Josué Euberma Diatewa1,3, Armel Landry Batchi-Bouyou1, Paul Macaire Ossou-Nguiét1,3, \\ Georges Moyen ${ }^{1}$
}

${ }^{1}$ Université Marien Ngouabi, Brazzaville, Congo

${ }^{2}$ Service de Soins Intensifs Pédiatriques, CHU de Brazzaville, Brazzaville, Congo

${ }^{3}$ Service de Neurologie, CHU de Brazzaville, Brazzaville, Congo

Email: engoba_m@yahoo.fr

How to cite this paper: Moyen, E., Mpandzou, G.A., Boukoulou, M.J.D., Diatewa, J.E., Batchi-Bouyou, A.L., Ossou-Nguiét, P.M. and Moyen, G. (2021) Psychological Experience of Children and Adolescents with Homozygous Sickle Cell Disease in Brazzaville. Open Journal of Pediatrics, 11, 35-49.

https://doi.org/10.4236/ojped.2021.111004

Received: December 15, 2020

Accepted: February 6, 2021

Published: February 9, 2021

Copyright $\odot 2021$ by author(s) and Scientific Research Publishing Inc. This work is licensed under the Creative Commons Attribution International License (CC BY 4.0).

http://creativecommons.org/licenses/by/4.0/

\begin{abstract}
Introduction: Sickle cell disease, the most frequent hemoglobinopathy, is one of many causes of psychological repercussions. Objectives: To determine the prevalence of psychological disorders in children/adolescents living with sickle cell disease and to identify the associated factors. Patients and Method: An analytical cross-sectional study was conducted from June to September 2019 at the national sickle cell center and at the mother-child consultation of the University Hospital of Brazzaville. Children/adolescents aged six to 19 years old followed for sickle cell disease were included. Psychological disorders were assessed using the Diagnostic and Statistical Manual of Mental Disorders "DSM-5" which assesses depression and anxiety disorders, the Rosenberg Self-Esteem Scale, and the Brief Illness Perception Questionnaire which assesses representations of chronic diseases. SPSS 20.0 software was used for statistical analysis. Results: Out of 201 children/adolescents included, a drop in self-esteem was noted: $76.1 \%$, anxiety $29.9 \%$, depression $5.5 \%$ and a negative impact on daily life in all cases. These were significant negative consequences $39.3 \%$. Advanced age, duration of illness, delay in school and puberty, use of upper-level analgesics, number of complications and hospitalizations, and occurrence of complications were associated with psychological disorders. Conclusion: The frequency of psychological disorders during the experience of the child/adolescent living with sickle cell anemia, requires that education, behaviour change communication be strengthened in order to improve the quality of care.
\end{abstract}


Keywords

Sickle Cell Disease, Children/Adolescents, Psychological Experience, Brazzaville

\section{Introduction}

Sickle cell disease is a public health problem. According to the WHO about 300,000 children are born with sickle cell disease each year [1]. In Africa, the homozygous form affects around $2 \%$ of the population [1], including $1.22 \%$ in a pediatric population and $0.9 \%$ in newborns in Congo [2] [3]. It is responsible for both acute and chronic complications [4], as well as disturbances in psychosocial development [5] [6], including low self-esteem, negative feelings and depression [7] [8].

In Africa, the psychosocial experience of children/adolescents living with sickle cell disease is poorly documented [9] [10]. In Congo, only one study on the psychosocial experience of mothers of children with sickle cell disease is available [6]. In order to improve the psychological experience of children/adolescents living with sickle cell disease in Brazzaville, the objective of the study was to determine the prevalence of psychological disorders in children/adolescents living with sickle cell disease and to identify the associated factors.

\section{Patients and Methods}

An analytical cross-sectional study was carried out from June to September 2019 at the national sickle cell reference center and at the mother-child consultation of the Brazzaville University Hospital. Children/adolescents living with sickle cell disease followed in these centers constituted our study population. Those six to 19 years of age homozygous (hemoglobin $S$ level $\geq 75 \%$ ), in the intercritical period were included. Heterozygosity or composites (AS, SC and thalassemia $S / \beta 0$ composites), unaccompanied children/adolescents and those whose parents were unwilling were not included. On these criteria, 201 subjects living with homozygous sickle cell disease were selected. The psychological experience was assessed using the diagnostic criteria of the American Psychiatric Association's Diagnostic and Statistical Manual of Mental Disorders, DSM-5 for depression [11]. The Likert-type Rosenberg scale for self-esteem [12] and the Brief Illness Perception Questionnaire (BIPQ) for cognitive and emotional representations [13] and an open-ended question comprising three words or expressions spontaneously associated with sickle cell disease by the subject.

The variables studied included a main variable: the psychological experience of the disease and secondary variables: socio-demographic, the circumstances of discovery of the disease by the subject, the age at diagnosis, the duration of the disease, the history of hospitalization, number and type of complications, nutritional [14] and pubertal status [15]; examination signs and treatment for the 
child/adolescent and, the number of children living with sickle cell disease in the family, marital status, socioeconomic and educational level, electrophoretic profile for collateral.

The statistical tests used were the Chi-square test and Fisher's exact test. The strength of the relationship between the variables was measured by Cramer's $\mathrm{V}$ $(<0.10$ : zero or very weak relationship; $\geq 0.10$ and $<0.20$ : weak relationship; $\geq 0.20$ and $<0.30$ : mean relationship, and $\geq 0.30$ : strong relationship). The significance threshold was set at $5 \%$.

\section{Ethical Considerations}

The study received approval from the Health Sciences Research Ethics Committee, the academic authorities of the Faculty of Health Sciences, the Director of the National Sickle Cell Center and the Head of the Monitoring Unit. children/ adolescents living with sickle cell anemia. Data confidentiality has been guaranteed.

\section{Results}

\subsection{Descriptive Data}

\subsubsection{The Psychological Experience}

Out of 201 subjects selected, the diagnostic criteria for depression and anxiety disorders were noted in 52 (25.9\%), depression in 11 (5.5\%) including six (2.98\%) mild and five (2.48 \%) moderate; anxiety in 60 subjects $(29.85 \%)$ including 36 (17.9\%) of social anxiety, 21 (10.4\%) of generalized anxiety disorder and one case of separation anxiety, panic disorder, respectively and post-traumatic stress. The decrease in self-esteem, noted in all cases, was low in 97 (48.2\%) cases, medium in 56 (27.9\%) cases and high in 48 (23.9\%) cases.

The impact of the disease on the subject's daily life was negative in all cases. These were small negative consequences $\mathrm{n}=122(60.7 \%)$ and large negative consequences $n=79$ (39.3\%). The answer to the question on the probable duration of the disease noted that it was perceived as curable by 155 (77.1\%) subjects and chronic by $46(22.9 \%)$.

A poor ability to control symptoms of the disease was noted in $147(73.1 \%)$ subjects, with significant control in 54 (26.9\%). The subjects' perception of the importance and effectiveness of treatment according to item 4 shows poor control of the treatment in 26 (12.9\%) subjects and good control in 175 (87.1\%). The subjects' personal experience perception of symptoms was poor in 129 (64.2\%) and good in $72(35.8 \%)$. The distribution of subjects according to their concerns about the disease showed that it was low 138 (68.7\%) and high in 63 (31.3\%). The subjects' perception of understanding of the disease was low in 152 (75.6\%) and good in 49 (24.4\%), the emotional impact of the disease showed weak negative emotions in 106 (52.7\%) and significant in 95 (47.3\%). A feeling of fear in 82 (40.8\%\%); sadness in $69(34.3 \%)$ and anger in 54 (26.9\%).

The knowledge of the cause assessed by the ability to list up to three probable 
causes of the disease showed that at least one cause was mentioned by 77 (38.3\%) subjects. The various causes mentioned were grouped into four categories: hereditary "linked to a fault of the parents" $\mathrm{n}=43$ (46.7\%); behavioral "intense physical or sports activity, my own fault, stress, non-compliance with therapy, refusal to put on a sweater, refusal to use hot water, cold" $\mathrm{n}=37$ (40.2\%); supernatural "sorcery, for lack of God, a coincidence", inexplicable "n $=8$ (8.7\%); linked to a blood abnormality "abnormal blood, decreased blood, fragile red blood cells" $n=3$ (3.3\%). Three words or phrases were spontaneously associated with sickle cell disease in 111 (55.2\%) subjects, one or two words in $72(35.8 \%)$ and no words in 18 (9\%) (Table 1).

Table 1. Words or expressions associated with sickle cell disease by the subjects.

\begin{tabular}{|c|c|}
\hline Category & Words or phrases \\
\hline Pain $(\mathrm{n}=109)$ & $\begin{array}{l}\text { "Pain" (34), "ache" (10), "pain in the bones" (31), } \\
\text { "stomach pain" (18), "headache" (8), "crying" (6), } \\
\text { "screams" (2). }\end{array}$ \\
\hline $\begin{array}{l}\text { Stigma and limits } \\
\qquad(\mathrm{n}=34)\end{array}$ & $\begin{array}{l}\text { "Pain" (34), "ache" (10), "pain in the bones" (31), } \\
\text { "stomach pain" (18), "headache" (8), "crying" (6), } \\
\text { screams" (2). }\end{array}$ \\
\hline Disease $(n=166)$ & 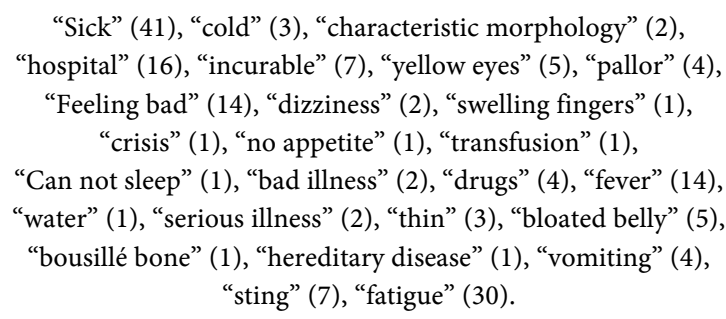 \\
\hline Feelings $(\mathrm{n}=58)$ & 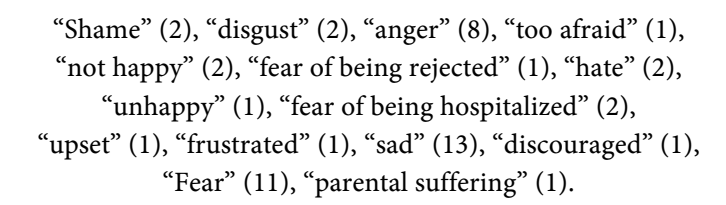 \\
\hline Death $(n=16)$ & $\begin{array}{l}\text { "Death" (11), "dead before } 25 \text { " (1), "short life" (1), } \\
\text { "early death" (1), "fear of death" (2). }\end{array}$ \\
\hline Battle $(n=23)$ & $\begin{array}{l}\text { "Stop being sad" (1), "want to be like others" (1), } \\
\text { "difficult" (3), "be strong" (4), "cure" (8), "hope" ( 6). }\end{array}$ \\
\hline Blood $(n=26)$ & $\begin{array}{l}\text { "Blood" (7), "red blood cells" (1), "decrease in blood" (8), } \\
\text { "anemia" (4), "abnormal blood" (2), } \\
\text { "deformation of red blood cells" (4). }\end{array}$ \\
\hline Misunderstanding $(\mathrm{n}=2)$ & "Sorcery" (1), "does not understand anything" (1). \\
\hline
\end{tabular}

$\mathrm{n}$ : number; in parenthesis: number of times the phrase or word has been mentioned. 


\subsubsection{Sociodemographic Characteristics of the Subjects}

The median age of the subjects was 12 years with an interquartile range between 9 and 15 years. These were 107 (53.2\%) girls and 94 (46.8\%) boys, sex ratio 0.88 . They were 6 to 9 years old $n=57$ (28.3\%), 10 to 12 years old $n=51(25.4 \%), 13$ to 15 years old $n=47(23.4 \%)$ and 16 to 19 years old $n=46(22.9 \%)$. They were supported by both parents $n=103(51.2 \%)$, the father $n=32(15.9 \%)$, the mother $\mathrm{n}=54(26.9 \%)$ and a guardian $\mathrm{n}=12(6.0 \%)$. They were the only child of the couple $n=23(11.4 \%)$, a couple of 2 to 3 children $n=91(45.3 \%)$ and more than three children $n=87$ (43.3\%). He was the couple's first child $n=61$ (30.3), second $n=54(26.9 \%)$ and over two $n=43(21.4 \%)$. The child was the only one in the family living with sickle cell disease $\mathrm{n}=159(79.1 \%)$ and there was more than one $\mathrm{n}=42(20.9 \%)$. These were children attending school in all cases, including $102(50.7 \%)$ in primary, $65(32.3 \%)$ in college, $29(14.4 \%)$ in high school and $5(02.5 \%)$ at university. Academic performance was poor in $54(26.9 \%)$ subjects, average in $96(47.8 \%)$ and good in 51 (25.4\%), academic delay was noted in 32 (15.9\%) subjects and absenteeism in 43 (21.4\%).

\subsubsection{Sociodemographic Characteristics of Parents}

The parents lived as a couple $\mathrm{n}=105(52.2 \%)$, single or single parent $\mathrm{n}=58$ (28.9\%), they were step families $\mathrm{n}=34(16.2 \%)$ and the parents were deceased $\mathrm{n}$ $=4(2.0 \%)$. The socioeconomic level was low $\mathrm{n}=51(25.4 \%)$, medium $\mathrm{n}=106$ (52.2\%), high $\mathrm{n}=44(21.9)$. The level of education was primary $\mathrm{n}=16(8 \%)$, secondary $\mathrm{n}=135(67.2 \%)$, higher $\mathrm{n}=45(22.4 \%)$ for mothers versus primary $\mathrm{n}$ $=3(1.5 \%)$, secondary $\mathrm{n}=108(55.7 \%)$, higher $\mathrm{n}=77$ (38.3\%) for fathers. Five $(2.5 \%)$ mothers versus $\mathrm{n}=13(6.5 \%)$ fathers were not in school. The electrophoretic profile was known for 47 (23.4\%) mothers versus 32 (16.0\%) fathers. The mothers were heterozygous in all cases versus $\mathrm{n}=31(15.5 \%)$ heterozygous fathers and one homozygous.

\subsection{Clinical Features}

The median age at diagnosis was three years with interquartile range between one and six years, including 145 (72.1\%) between three months and five years, 41 (20.4\%) between 6 and 10 years and 15 (7.5\%) between 11 and 16 years old. The circumstances of discovery were: bone pain $n=119(59.2 \%)$, anemia $\mathrm{n}=39$ (19.4\%), infection $\mathrm{n}=27$ (13.4\%), abdominal pain $\mathrm{n}=11(5.5 \%)$, a systematic assessment $\mathrm{n}=4(2 \%)$ and one $(0.5 \%)$ priapism.

The duration of the disease was 0 to 5 years $\mathrm{n}=67(33.3 \%), 6$ to 10 years $\mathrm{n}=$ $76(37.8 \%), 11$ to 15 years $n=43(21.4 \%)$ and 16 to $18 n=15(7.5 \%)$. The status of people living with sickle cell disease was known by 107 (53.2\%) subjects aged: 6 to 9 years $\mathrm{n}=10(9.3 \%), 10-12$ years $\mathrm{n}=69(64.5 \%), 13-15$ years $\mathrm{n}=25$ (23.4\%) and $16-18$ years $n=3(2.8 \%)$. The information was obtained from one or both parents $n=82(76.6 \%)$, from the attending physician $n=20(18.7 \%)$ and following personal research $n=5(4,7 \%)$. A history of hospitalization was found in $190(94.5 \%)$ subjects. The number of previous hospitalizations ranged from 1 
to $5 \mathrm{n}=140(69.7 \%), 6$ to $10 \mathrm{n}=39(19.4 \%)$ and more than $10 \mathrm{n}=11(5.5 \%)$.

The history of complication found in 138 (68.6\%) subjects was divided into acute complication $\mathrm{n}=110(54.7 \%)$, chronic $\mathrm{n}=7(3.5 \%)$ and acute and chronic $\mathrm{n}=21(10.4 \%)$. The complication was single $\mathrm{n}=71$ (35.3\%), two complications $\mathrm{n}=49(24.4 \%)$ and three to five $\mathrm{n}=18(9.0 \%)$. Vaso-occlusive crises were noted one to three times $n=88(42.8 \%)$ and more than three times $n=19(9.5 \%)$. A history of deglobulization crisis one to three times $n=68(33.8 \%)$ and more than three times $\mathrm{n}=3(1.5 \%)$.

Subjects were eutrophic $n=159(79.1 \%)$ and emaciated $n=42(20.9 \%)$. Growth retardation was noted $n=21(10.4 \%)$, puberty delay $n=5(2.4 \%)$, jaundice $n=118$ (58.7\%), splenomegaly $n=27(13.4 \%)$ and functional impotence $n=8(4.0 \%)$.

The treatment was: folic acid supplementation in all cases, analgesic $n=187$ (93.0\%), level $1 \mathrm{n}=155$ (82.9\%), level $2 \mathrm{n}=17$ (9.1\%) and stage $3 \mathrm{n}=15(8 \%)$.

Blood transfusion $n=168$ (83.6\%); penicillin $n=24(11.9 \%)$ subjects. The indications for hydroxyurea $\mathrm{n}=33(16.4 \%)$ were recurrence of painful and anemic attacks $n=13(39.4 \%)$, stroke $n=5(15.2 \%)$, ATS, priapism and heart disease one case each. In $12(36.4 \%)$ subjects the indication was not specified.

\subsection{Analytical Study}

The onset of depression in children/adolescents is associated with age, the duration of the disease, the number of hospitalizations, the number and type of complications and the use of analgesics (Table 2). According to Cramer's V, the association was weak with the number of hospitalizations; moderate with the length of the disease, the current age, the number and type of complications and strong with the use of analgesics.

Illness duration, performance, and academic delay are associated with anxiety (Table 3). A weak association for taking hydroxyurea, medium for school and puberty delay and strong for age and duration of the disease.

The drop in self-esteem is associated with age, the duration of the illness and the existence of a school delay, the number of hospitalizations and the use of analgesics (Table 4). This is a weak association for the number of hospitalizations; average for school delay, duration of illness and analgesics and strong for age.

\section{Discussion}

The course of sickle cell disease is punctuated by vaso-occlusive crises, deglobulization, infections [4] but also the ever possible occurrence of psychological repercussions [5]. The objective of the study was to identify the psychological disorders likely to interfere with the experience of the child/adolescent living with sickle cell disease as well as the associated factors relating thereto. The study framework as well as the size of the sample justifies why the results obtained can be applied to the entire infant and juvenile population living with sickle cell disease in Brazzaville, although a pitfall relating to certain open questions could lead to problems: negative emotional reactions. 
Table 2. Relationship between socio-demographic and clinical characteristics and depression.

\begin{tabular}{|c|c|c|c|c|c|c|}
\hline \multirow{3}{*}{\multicolumn{2}{|c|}{ Variables }} & \multicolumn{5}{|c|}{ Depression } \\
\hline & & \multicolumn{2}{|c|}{ Yes } & \multicolumn{2}{|c|}{ No } & \multirow{2}{*}{$p($ Khi- 2} \\
\hline & & $\mathrm{n}$ & $\%$ & $\mathrm{n}$ & $\%$ & \\
\hline \multirow{4}{*}{$\begin{array}{c}\text { Age range } \\
\text { (years) }\end{array}$} & $6-9$ & - & - & 57 & 30.0 & \multirow{4}{*}{$<0.001^{\star}$} \\
\hline & $10-12$ & - & - & 51 & 26.8 & \\
\hline & $13-15$ & 2 & 18.2 & 45 & 23.7 & \\
\hline & $16-19$ & 9 & 81.8 & 37 & 19.5 & \\
\hline \multirow{4}{*}{$\begin{array}{l}\text { Duration of illness } \\
\text { (years) }\end{array}$} & $0-5$ & 1 & 09.1 & 66 & 34.7 & \multirow{4}{*}{$0.006^{*}$} \\
\hline & $6-10$ & 2 & 18.2 & 74 & 39.0 & \\
\hline & $11-15$ & 5 & 45.5 & 38 & 20.0 & \\
\hline & $16-18$ & 3 & 27.3 & 12 & 6.3 & \\
\hline \multirow{4}{*}{$\begin{array}{c}\text { Number of } \\
\text { hospitalizations }\end{array}$} & 0 & 1 & 09.1 & 10 & 5.3 & \multirow{4}{*}{$0.040^{*}$} \\
\hline & $1-5$ & 4 & 36.4 & 136 & 71.6 & \\
\hline & $6-10$ & 5 & 45.5 & 34 & 17.9 & \\
\hline & $>10$ & 1 & 09.1 & 10 & 5.3 & \\
\hline \multirow{4}{*}{$\begin{array}{c}\text { Number of } \\
\text { complications }\end{array}$} & 0 & 1 & 09.1 & 62 & 32.6 & \multirow{4}{*}{$0.039^{*}$} \\
\hline & 1 & 6 & 54.5 & 65 & 34.2 & \\
\hline & 2 & 1 & 09.1 & 48 & 25.3 & \\
\hline & $>3$ & 3 & 27.3 & 15 & 7.9 & \\
\hline \multirow{4}{*}{$\begin{array}{c}\text { Type of } \\
\text { complications }\end{array}$} & Non & 1 & 09.1 & 62 & 32.6 & \multirow{4}{*}{$0.043^{*}$} \\
\hline & Acute & 6 & 54.5 & 104 & 54.7 & \\
\hline & Chronic & - & - & 7 & 3.7 & \\
\hline & Acute and chronic & 4 & 36.4 & 17 & 8.9 & \\
\hline \multirow{5}{*}{ Taking analgesics } & None & 1 & 09.1 & 13 & 6.8 & \multirow{5}{*}{$<0.001^{\star}$} \\
\hline & Tier 1 & 2 & 18.2 & 153 & 80.5 & \\
\hline & & & & & & \\
\hline & Tier 2 & 2 & 18.2 & 15 & 7.9 & \\
\hline & Tier 3 & 6 & 54.5 & 9 & 4.7 & \\
\hline
\end{tabular}

n: number, \%: percentage; ${ }^{*} \mathrm{p}$ calculated by Fisher's exact test. 
Table 3. Relationship between socio-demographic and clinical characteristics and anxiety.

\begin{tabular}{|c|c|c|c|c|c|c|}
\hline \multirow{3}{*}{ Variables } & & \multicolumn{5}{|c|}{ Anxiety } \\
\hline & & \multicolumn{2}{|c|}{ Yes } & \multicolumn{2}{|c|}{ No } & \multirow{2}{*}{$p($ Khi- 2$)$} \\
\hline & & $\mathrm{n}$ & $\%$ & $\mathrm{n}$ & $\%$ & \\
\hline \multirow{5}{*}{ Age (years) } & $6-9$ & 2 & 04.1 & 55 & 36.2 & \multirow{5}{*}{$<0.001$} \\
\hline & $10-12$ & 3 & 06.1 & 48 & 31.6 & \\
\hline & & & & & & \\
\hline & $13-15$ & 20 & 40.8 & 27 & 17.8 & \\
\hline & $16-19$ & 24 & 49.0 & 22 & 14.5 & \\
\hline \multirow{4}{*}{$\begin{array}{l}\text { Duration of illness } \\
\text { (years) }\end{array}$} & $0-5$ & 8 & 16.3 & 59 & 38.8 & \multirow{4}{*}{$<0.001^{*}$} \\
\hline & $6-10$ & 14 & 28.6 & 62 & 40.8 & \\
\hline & $11-15$ & 21 & 42.9 & 22 & 14.5 & \\
\hline & $16-18$ & 6 & 12.2 & 9 & 5.9 & \\
\hline \multirow{3}{*}{ School performance } & Low & 20 & 40.8 & 34 & 22.4 & \multirow{3}{*}{0.027} \\
\hline & Mean & 21 & 42.9 & 75 & 49.3 & \\
\hline & Good & 8 & 16.3 & 43 & 28.3 & \\
\hline \multirow{3}{*}{ School delay } & No & 33 & 67.3 & 136 & 89.5 & \multirow{3}{*}{0.001} \\
\hline & & & & & & \\
\hline & Yes & 16 & 32.7 & 16 & 10.5 & \\
\hline \multirow{3}{*}{ School absenteeism } & No & 38 & 77.6 & 120 & 78.9 & \multirow{3}{*}{0.843} \\
\hline & & & & & & \\
\hline & Yes & 11 & 22.4 & 32 & 21.1 & \\
\hline \multirow{2}{*}{$\begin{array}{l}\text { Pubertal delay } \\
\quad(\mathrm{n}=144)\end{array}$} & No & 45 & 91.8 & 94 & 98.9 & \multirow{2}{*}{$0.045^{*}$} \\
\hline & Yes & 4 & 8.2 & 1 & 1.1 & \\
\hline \multirow{2}{*}{$\begin{array}{l}\text { Blood transfusion } \\
\text { concept }\end{array}$} & No & 5 & 10.2 & 28 & 18.4 & \multirow{2}{*}{0.194} \\
\hline & Yes & 44 & 89.8 & 124 & 81.6 & \\
\hline \multirow{3}{*}{ Taking hydroxyurea } & No & 36 & 73.5 & 132 & 86.8 & \multirow{3}{*}{0.044} \\
\hline & & & & & & \\
\hline & Yes & 13 & 26.5 & 20 & 13.2 & \\
\hline
\end{tabular}

n: number, \%: percentage; ${ }^{*}$ p calculated by Fisher's exact test. 
Table 4. Relationship between socio-demographic and clinical characteristics and selfesteem.

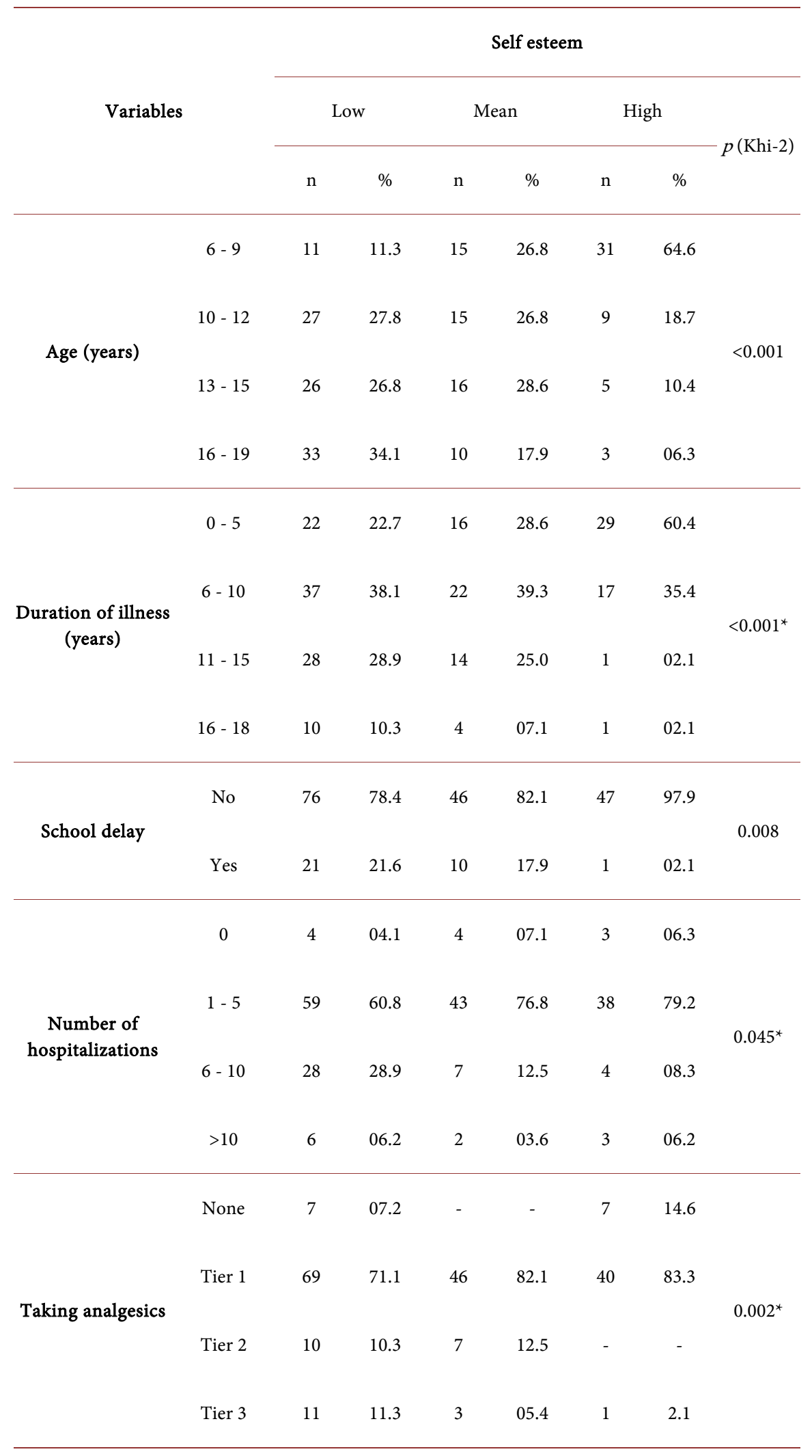

n: number; \%: percentage; ${ }^{*} \mathrm{p}$ calculated by Fisher's exact test. 


\subsection{Prevalence of Psychological Experience}

The prevalence of depression estimated at $5.5 \%$ is higher than in the general population: $0.5 \%$ in children under $12 \%$ and $3 \%$ in adolescents 12 to 18 years [16]. In an adult population living with sickle cell disease, it is twice as high as in controls [17]. In a study where only parents/guardians were interviewed, its prevalence was $86.4 \%$ according to Lukoo in DRC [9]. The prevalence depends on the study population, Gernet reports $9.1 \%$ when the questionnaire was sent to parents versus $36 \%$ when it was addressed to children [7], but also according to the type of questionnaire. Such as the Mini-International Neuropsychiatric Interview for Children and Adolescent (MINI-Kid) structured on the basis of DSM-4 and CIM-10 [10], MDI-C in Belgium and DRC with a prevalence of 25\% [8] [9] and the Children Depression Invotory "CDI" questionnaire in France with a prevalence of $5 \%$ [18].

The prevalence of anxiety: $29.9 \%$ is higher than in the general population of children/adolescents aged 5 to 18 years: $5 \%$ according to Bailey [16]. Fear of care, the invasiveness of treatments and the projections they make of the outcome of the disease such as the idea of death are the contributing factors [19]. Prevalences as high as ours are reported in children aged 6 to 12 by Lambotte: $25 \%$ [8] and in those aged 8 to 17 by Wagner: $41.3 \%$ [20]. The high prevalence of anxiety disorders is a constant during chronic pathologies such as asthma: $25.7 \%$ [21] and epilepsy: 33\% [22].

The drop in self-esteem is like depression and anxiety, disturbed during the chronic illness experience as for $75 \%$ of adolescents living with sickle cell disease in Seigel's study [23] and 76.1\% in our study. According to Alvin, the child/ adolescent living with sickle cell disease has a spontaneous tendency to isolate itself and to reduce social, cultural or leisure activities [5]. The morphological aspect is also one of the stigmatizing factors that are the source of the deterioration in the quality of life [24]. For Lambotte, it is the feeling of being different from his fellows [8].

\subsection{Representations of Sickle Cell Disease}

For the family unit, the child/adolescent living with sickle cell disease is sometimes overprotected with a tendency to exempt it from heavy responsibilities [25], sometimes considered as a burden that we want to get rid of, a "financial pit" or "like the misfortune of the family" [10] but also, a dangerous and fatal illness, source of worry and expense [26].

As with all chronic diseases, the experience of sickle cell disease is characterized by a significant physical, psychological and social impact [26] [27] [28] [29]. Thus, social dysfunction was noted in $39.3 \%$ and chronicity of the disease recognized in $22.9 \%$ by Girot [30]. According to Diop, only $26.9 \%$ of adults living with sickle cell disease have symptoms under control [31]. CVOs, formidable complications, the object of addiction to treatment, constitute the reality of the disease over which the subject has no power or control [5]. Also, recurrent painful 
crises, little or badly relieved, are experienced as traumatic events that leave a negative feeling [32].

Sickle cell disease is a taboo in African representation, an obstacle to any research and information initiative [33]. In this study, the understanding of the disease is $24.4 \%$. In the West, according to Oudin-Doglioni, the consequences of sickle cell disease on life are perceived by $50 \%$ of adults, chronicity by $60 \%$ and knowledge of treatment by $62.5 \%$ [34]. The representations of the disease are identical in adults and grandchildren. It has been established that subjects who have a poor understanding of the disease perceive neither the negative consequences nor the possibility of chronicity and are less concerned [30] [35]. The causes of sickle cell disease are also variously perceived. Thus, a cause is attributed to it in less than half of the cases in Gernet's pediatric series [7], 38.3\% in our study, due to young age, lack of information, ignorance of the status. electrophoresis by parents and the low contribution of medical personnel to the announcement of the diagnosis. All these factors explain why in Africa, sickle cell anemia is sometimes associated with a mystical phenomenon [33] as evidenced by the words of a 12-year-old girl who said: "I am sick because the members of my mother's family didn't want her to have a daughter and they put a spell on her". At the same time, the negative emotions generated by fear $47.3 \%$ are the consequence of the fear of another crisis, exclusion or death. Speaking of which, a 16-year-old said, "I have trouble sleeping, it's like I'm choking. I don't know if it's in my head, I'm afraid it will come back. I don't know if it can come back and the doctors are not by my side [...] I have known young people who had it who died at 28 years old..." [33]. Negative feelings are reported in $86 \%$ of subjects in the Gernet series [7].

Because of its near permanence in all chronic diseases, pain is among the most widely used words associated with sickle cell disease (91\%). It is actually a reference to the most recent or vivid memory. A patient, said for a headache of tumor origin "the pain was there [...] it quickly became my only reason for being, the preoccupation of each of my seconds, my universe was reduced to my cranial box..." [35]. For Jeoffrion, the words "suffering" and "pain" are at the heart of social representations of illness [36], "daily battle and death" for Gernet [7]. Another cause of psychological disturbance in children/adolescents living with sickle cell disease is the always possible onset of delayed puberty [24] [37]. They say they are different from others and concerned about their future as adults. Speaking of which, the mother of a teenage girl said: "At 13 she doesn't have breasts yet, now that she's growing up I wonder about her life as a woman. Will she be able to have children like everyone else?" [33].

\subsection{Factors Associated with Psychological Disorders}

Psychological disorders are associated with socio-demographic, clinical, therapeutic and evolutionary factors. Factors associated with depression vary across studies. The chronicity of the disease, the dependence on the medical environ- 
ment, the unpredictable nature of the pain crises and frequencies as well as the increased stress for Alao [19], the chronicity of the disease, the age, the number of hospitalizations, the number and the type of complications and analgesic intake for our study. Age, illness duration, performance, and academic delay are associated with anxiety disorders [5]. Decreased self-esteem is associated with age, the duration of the illness and the existence of a school delay, the number of hospitalizations and the use of analgesics.

\subsection{Intensity of the Relationship between the Variables}

Age and duration of illness are associated with depression, anxiety, and low selfesteem ( $\mathrm{p} 0.001$ ), with a strong association for age. The degree of depression, anxiety and low self-esteem is higher in older subjects due to the level of understanding, study and length of time the disease has been experienced. Thus, the psychic impact increases with the duration of the illness. The same relationship is established in adults [17] [38] [39].

The between depression and type of complications was moderate, low with the number of hospitalizations. Hassan and Wilson Shaeffer report in addition to the number of hospitalizations, a relationship between depression, the number of painful attacks and blood transfusions [39] [40].

\section{Conclusion}

The psychological experience of the child/adolescent living with sickle cell disease in Brazzaville is marked by a high frequency of anxiety, low self-esteem, depression and negative representations of the disease. The associated factors are the advanced age of the subjects, the chronicity of the disease, the number of complications and hospitalizations, the combination of acute and chronic complications, the use of upper-level analgesics and hydroxyurea, educational and pubertal delay.

\section{Conflicts of Interest}

The authors declare no conflicts of interest regarding the publication of this paper.

\section{References}

[1] Modell, B. and Darlinson, M. (2008) Global Epidemiology of Haemoglobin Disorders and Derived Service Indicators. Bulletin of the World Health Organization, 86, 480-487. https://doi.org/10.2471/BLT.06.036673

[2] Djembo-Taty, M., Tchiloemba, M. and Galacteros, F. (1986) Etude épidémiologique des hémoglobinopathies au Congo chez 2257 nouveau-nés. Nouvelle Revue Francaise D' Hematologie, 28, 249-251.(French with English Abstract)

[3] Mpemba Loufoua, A.B., Makoumbou, P., Mabiala Babela, J.R., Nakahonda, C., Mayanda, F. and Nzingoula, S. (2010) Dépistage néonatal de la drépanocytose au Congo Brazzaville. Annales de IUniversité Marien Ngouabi, 11, 21-25. (French with English Abstract) 
[4] Ngolet, L.O., Moyen, E., Kocko, I., Elira Dokekias, A, Mombouli, J.V. and Moyen, G.M. (2016) Sickle Cell Disease Healthcare Cost in Africa: Experience of the Congo. Anemia, 2016, Article ID: 2046535. https://doi.org/10.1155/2016/2046535

[5] Alvin, P., De Tournemire, R., Anjot, M.N. and Vuillemin, L. (2003) Chronic Illness in Adolescence: Ten Relevant Questions. Archives de Pédiatrie, 10, 360-366. https://doi.org/10.1016/S0929-693X(03)00081-2

[6] Nika, E.-R., Mabiala Babela, J.-R., Moyen, E., Kambourou, J., Lombet, L., Mouanga Mpolo, P. and Moyen, G. (2016) Psychosocial Issues of Mothers Whose Children Have Sickle Celldisease. Archives de Pédiatrie, 23, 1135-1140. https://doi.org/10.1016/j.arcped.2016.08.010

[7] Gernet, S. and Mestre, C. (2011) Runel-Belliard. Emotional Representations of the Illness among 22 Sickle Cell Children. Neuropsychiatrie de P Enfance et de P Adolescence, 59, 404-410. https://doi.org/10.1016/j.neurenf.2011.05.005

[8] Lambotte, I., De Coster, L., Ferster, A. and Delvenne, V. (2017) Psychological Development Study of the Child with Sickle Cell Anemia. Neuropsychiatrie de P Enfance et de P Adolescence, 67, 61-69. https://doi.org/10.1016/j.neurenf.2018.05.001

[9] Lukoo, R.N., Ngiyulu, R.M., Mananga, G.L., Gini-Ehungu, J.L., Ekulu, P.M., Tshibassu, P.M., et al. (2015) Depression in Children Suffering from Sickle Cell Anemia. Journal of Pediatric Hematologyl Oncology, 37, 20-24. https://doi.org/10.1097/MPH.0000000000000276

[10] Mbassa Menick, D. and Ngoh, F. (2001) Maltraitance Psychologique d'enfants drépanocytaires au Cameroun: Description et analyse de cas. Médecine Tropicale, 61, 163-168. (French with English Abstract)

[11] American Psychiatric Association (2013) Diagnostic and Statistical Manual of Mental Disorders: DSM-5. 5th Edition, American Psychiatric Association, Washington DC. https://doi.org/10.1176/appi.books.9780890425596

[12] Vallieres, E.F. and Vallerand, R.J. (1990) Traduction et validation Canadienne-Française de l'échelle de l'estime de soi de Rosenberg. International Journal of Psychology, 25, 305-316. (French with English Abstract) https://doi.org/10.1080/00207599008247865

[13] Broadbent, E., Petrie, K.J., Main, J. and Weinman, J. (2006) The Brief Illness Perception Questionnaire. Journal of Psychosomatic Research, 60, 631-637. https://doi.org/10.1016/j.jpsychores.2005.10.020

[14] De Onis, M., Onyango, A.W., Borghi, E., Siyam, A., Nishida, C. and Siekmann, J. (2007) Development of a WHO Growth Reference for School-Aged Children and Adolescents. Bulletin of the World Health Organization, 85, 660-667. https://doi.org/10.2471/BLT.07.043497

[15] Bourillon, A., Benoist, G. and Delacourt, C. (2014) Pédiatrie. 6th Edition, Elsevier Masson, Paris.

[16] Bailey, D., Bouvard, M., Casadebaig, F., Corcos, M., Fombonne, E., Gorwood, P., Gressens, P., Krebs, M.O., Le Normand, M.T., Martinot, J.L., Ouakil-Purper, D., De Schonen, M.S. and Verdoux, H. (2003) Troubles Mentaux: Dépistage et Prévention chez l'enfant et l'adolescent. Institut National de la Santé et de la Recherche Médicale, Paris. (French with English abstract)

[17] Asnani, M.R., Fraser, R., Lewis, N.A. and Reid, M.E. (2010) Depression and Loneliness in Jamaicans with Sickle Cell Disease. BMC Psychiatry, 10, Article No. 40. https://doi.org/10.1186/1471-244X-10-40

[18] Josset-Raffet, E., Duparc-Alegria, N., Thiollier, A.F., Dugue, S., Faye, A., Ithier, G., Holvoet-Vermaut, L., Missud, F., Abdoul, H. and Benkerrou, M. (2015) Perception 
and Assessment of Pain by Caregiver and Adolescent with Sickle Cell Disease: The Impact of the Patient's Anxiety. Archives de Pédiatrie, 23, 143-149. https://doi.org/10.1016/j.arcped.2015.11.013

[19] Alao, A.O. and Cooley, E. (2001) Depression and Sickle Cell Disease. Harvard Review of Psychiatry, 9, 169-177. https://doi.org/10.1080/10673220127896

[20] Wagner, J.L., Connelly, M., Brown, R.T., Taylor, L., Rittle, C. and Wall-Cloues, B. (2004) Predictors of Social Anxiety in Children and Adolescents with Sickle Cell Disease. Journal of Clinical Psychology in Medical Settings, 11, 243-252. https://doi.org/10.1023/B:JOCS.0000045344.05747.d3

[21] Goodwin, R.D., Messino, K., Bregante, A., Hoven, C.W. and Kairam, R. (2005) Prevalence of Probable Mental Disorders among Pediatric Asthma Patients in an Inner-City Clinic. Journal of Asthma, 42, 643-647.

https://doi.org/10.1080/02770900500264770

[22] Caplan, R., Siddarth, P., Gurbani, S., Hanson, R., Sankar, R. and Shields, W.D. (2005) Depression and Anxiety Disorders in Pediatric Epilepsy. Epilepsia, 46, 720-730. https://doi.org/10.1111/j.1528-1167.2005.43604.x

[23] Seigel, W.M., Golden, N., Gough, J.W., Lashley, M.S. and Sacker, I.M. (1990) Depression, Self-Esteem and Life Events in Adolescents with Chronic Diseases. Journal of Adolescent Health Care, 11, 501-504. https://doi.org/10.1016/0197-0070(90)90110-N

[24] Mabiala Babela, J.R., Mouyabi Mberi, F.D., Ollandzobo Ikobo, L.C., Nika, E.R., Ngoulou, B.V.S. and Missambou Mandilou, S.V. (2018) Homozygous Sickle Cell Children Treated with Hydroxyurea in Brazzaville (Congo). Bulletin de la Société de Pathologie Exotique, 111, 46-50. https://doi.org/10.3166/bspe-2018-0006

[25] Njifon Nsangou, H. and Scelles, R. (2019) Sickle Cell Disease and Siblings: A Crossover Look at the Experiences of a Sister and Abrother of a Sick Child. Journal de Pédiatrie et de Puériculture, 32, 75-84.

[26] Kalina, K., Barma, M., Adeyosola Adeniyi, A., Kpassagou, L.B. and Gbati, K.Y. (2018) Psychological Effects of the Sickle-Cell Sickness on Parents in Lome. International Journal of Innovation and Applied Studies, 23, 732-744.

[27] Bouquinet, E., Balestra, J., Bismuth, E., Bruna, A.L., Gallet, S., Harvet, G., Jean, S. and Jousselme, C. (2008) Chronic Disease and Childhood: Image of the Body, Psychic Stakes and Therapeutic Alliance. Archives de Pédiatrie, 15, 462-468. https://doi.org/10.1016/j.arcped.2008.01.008

[28] Spizzo-Guellati, A.H., Chabrat, M., Paris, H., Moreau, F., Mansilla, M., Squillaci, A. and Kessler, L. (2014) Representations of Diabetic Adolescents by the Nursing Staff in Adult vs. Pediatric Diabetology. Médecine des Maladies Métaboliques, 8, 319323. https://doi.org/10.1016/S1957-2557(14)70807-7

[29] Boutry, L., Matheron, I. and Bidat, E. (2001) When Prescriptions Are Not Followed... Thoughts about Health Beliefs and Representations. The Example of an Asthmatic Patient. Revue Française d Allergologie et d Immunologie Clinique, 41, 470 476. https://doi.org/10.1016/S0335-7457(01)00056-9

[30] Girot, R. and De Montalembert, M. (2006) Drépanocytose chez l'enfant. Pédiatrie, 4, A20. (French with English Abstract)

[31] Diop, S., Diop, D., Seck, M., Guèye, Y., Faye, A. and Dièye, T.N., et al. (2010) Predictive Factors of Chronic Complications in Adult Sickle Cell Anemia Patients in Dakar, Senegal. Medecine Tropicale, 70, 471-474.

[32] Josset-Raffet, E., Yi, M.K. and Benkerrou, M. (2016) Bodily and Psychic Trajectory of Pain in Children with Sickle Cell Disease. Neuropsychiatrie de P Enfance et de 
P Adolescence, 64, 131-138. https://doi.org/10.1016/j.neurenf.2016.01.003

[33] Gernet, S., Mestre, C. and Runel-Belliard, C. (2012) From Home to the "Host" Country: Illness Perception among 26 Families with Sickle-Cell Disease Followed-Up in Bordeaux, France. Journal de Pédiatrie et de Puériculture, 25, 309-315.

https://doi.org/10.1016/j.jpp.2012.08.003

[34] Oudin-Doglioni, D., Gay, M.C., Lehougre, M.P., Arlet, J.B. and Galactéros, F. (2018) Sickle Cell Disease Representation as a Determinant for Patient Compliance. Annales Médico-Psychologiques, Revue Psychiatrique, 177, 517-525. https://doi.org/10.1016/j.amp.2017.10.024

[35] Malka, J., Togora, A., Chocard, A.S., Faure, K. and Duverger, P. (2007) Psychic Impact Analysis in Somatic Chronic Disease among Adolescent Population. Neuropsychiatrie de P Enfance et de P Adolescence, 55, 149-153.

https://doi.org/10.1016/j.neurenf.2007.03.007

[36] Jeoffrion, C., Dupont, P., Tripodi, D. and Roland-Lévy, C. (2015) Social Representations of Illness: Comparison of "Expert" Knowledge and "Naïve” Knowledge. L'Encéphale, 42, 226-233. https://doi.org/10.1016/j.encep.2015.12.007

[37] M'Pemba-Loufoua, A.B. and Nzingoula, S. (2001) The Sexual Maturation Development of a Homozygoussickle Cell Affected Boy. 53 Study Cases. Medecine d Afrique Noire, 48, 5-10.

[38] Levenson, J.L., McClish, D.K., Dahman, B.A., Bovbjerg, V.E., Citero, V.A., Penberthy, L.T., Aisiku, I.P., Roberts, J.D., Roseff, S.D. and Smith, W.R. (2008) Depression and Anxiety in Adults with Sickle Cell Disease: The PiSCES Project. Psychosomatic Medicine, 70, 192-196. https://doi.org/10.1097/PSY.0b013e31815ff5c5

[39] Hasan, S.P., Hashmi, S., Alhassen, M., Lawson, W. and Castro, O. (2003) Depression in Sickle Cell Disease. Journal of the National Medical Association, 95, 533-537.

[40] Wilson Shaeffer, J.J., Gil, K.M., Burchinal, M., Kramer, K.D., Nash, K., Orringer, E. and Strayhorn, D. (1999) Depression, Disease Severity and Sickle Cell Disease. Journal of Behavioral Medicine, 22, 115-126. https://doi.org/10.1023/A:1018755831101 